\section{A Look Back: 2000 IPSA World Congress}

Members of the International Political Science Association gathered in Quebec City, Canada, from July 31 to August 5 for the organization's Twentieth World Congress. The theme of the conference, led by William Lafferty of the University of Oslo and attended by an estimated 1800 political scientists, was "World Capitalism, Governance and Community: Toward a Corporate Millennium."

APSA, a long-time IPSA member, was officially represented at the meeting by Walter Beach, HELDREF Publications; Paula McClain, Duke University; Catherine E. Rudder, APSA; Betty Glad, University of South Carolina; and Theodore Lowi, Cornell University. A former APSA president, Lowi completed his three-year term as IPSA president at the Quebec meeting. As one of his last official acts, he delivered the Karl Deutsch Memorial Lecture, "Our Millennium: Political Science Confronts the Global Corporate Economy."

Like APSA, IPSA holds its governance meetings in conjunction with its scholarly convention. The IPSA Council, composed of representatives and alternates of the 40 national members, governs IPSA and met three times, on August 1,2, and 4 , to conduct its business. Major developments included:

- John Coakley, University College Dublin, completed his sixyear term as general secretary of IPSA and will be succeeded by Guy LaChappelle of Concordia University, Quebec.

- Paula McClain was reelected to the Executive Committee, a subset of the Council that meets and makes decisions in the years between congresses. As immediate past president, Ted Lowi will continue to serve on the Executive Committee for another term.

- Dalchoong Kim of the Sejong Institute of South Korea was elected president of IPSA by the Council. President Kim ap- pointed Paula McClain as one of five IPSA vice presidents.

- It was announced that the next World Congress will be held in Durban, South Africa, from June 31 to July 4, 2003. Paula McClain and James Gibson, University of Houston, were appointed co-chairs of the Program Committee for the Durban meeting. The APSA delegation met with leaders of the Association of African Political Scientists to discuss ways APSA can help in seeking funds for the 2003 congress. Possibilities for APSA-AAPS collaboration over the longer term were also discussed.

- John Coakley presented an extensive written report on the activities of IPSA during the 1997-2000 period. Major issues the Executive Committee has addressed have included the representation of Research Groups in IPSA's governing bodies, the encouragement of women's participation in all aspects of IPSA, the location of future world congresses, and the selection of a new secretariat. Coakley announced the completion of several significant projects, including the publication and distribution of a handbook book on IPSA's newly codified policies and procedures, which has made IPSA a more transparent organization; the publication and distribution of a history of IPSA and of a directory of women members; the creation of a new, systematic subcommittee structure for the Executive Committee; the introduction of a new funding system and a revision of rules for IPSA's research committees; the continued professionalization of the International Political Science Review; and the extraordinary success of Political Science Abstracts, especially its CD-ROM editions. John Coakley's report is attached to the minutes of the Council meeting.

\section{Building Resources Abroad}

The American Political Science Association is committed to the internationalization of the study of political science. To that end, APSA annually donates subscriptions of the American Political Science Review and PS: Political Science and Politics to countries with weak or undervalued currencies. The Association currently sends journals to 42 institutions in East and Central Europe, countries of the former Soviet Union, and Sub-Saharan Africa. APSA participates in established projects such as the East and Central European Journal Donation Project and also makes donations to individual institutions. In 1997, following the cancellation of the ACLS-sponsored Sub-Saharan African Journal Donation Project, the Association began providing materials directly to 10 institutions in that region.

The APSA Council established a set of guidelines for making journal donafions to needy academic institutions and instituted an annual budget for such activities in the fall of 1997. New participants will be considered based on their institutional and financial needs, and their abilities to receive and catalogue the journals. Preference will be given to the institutions in countries with weak or undervalued currencies. For more information, please email international@apsanet.org.

\section{A Gift of Knowledge}

Helene Silverberg, a political scientist who is currently an attorney at Morrison and Foerester in San Francisco practicing antitrust and intellectual property litigation, recently donated her entire collection of political science books to the Georgian Political Science Association in Tbilisi, Georgia. The vice president of the Georgian Political Science Association, Ucha Nunuashvili, asked APSA for assistance in building a library and starting a journal for the dissemination of political science research in Georgia. To that end, APSA has sent the GPSA copies of the current volume of APSR and PS as well as a small collec tion of political science books. Dr. Silverberg contacted APSA and asked to whom she could donate her collection in July, shortly after the Georgians contacted APSA, and we connected the two parties. She generously paid all delivery charges for her donation. We are grateful for her generosity and encourage others to follow her example. For more information contact Sue Davis at sdavis@apsanet.org. 